\title{
There is no stopping covid-19 without stopping racism
}

\author{
As Martin Luther King Jr said, "In the end, we will remember not the words of our enemies but the \\ silence of our friends"
}

\author{
Abraar Karan internal medicine physician ${ }^{1}$, Ingrid Katz associate faculty director ${ }^{2}$ \\ 'Brigham and Women's Hospital, Boston, Massachusetts, USA; ${ }^{2}$ Harvard Global Health Institute, Cambridge, Massachusetts, USA
}

Doctors like us who have been working on the covid-19 response in the US have been told to "stay in our lane" as the murder of George Floyd has triggered the largest anti-racism movement since the 1990s.

Unsurprisingly, many prominent physicians and public health leaders have remained relatively silent on the topic of racism, which has historically been falsely politicised as a matter of partisanship. It is not. And it is our lane.

Racism has always been a public health problem. Racism kills our patients, our neighbours, our colleagues, our leaders.

A number of people who see the protests as possible drivers of more covid-19 cases have suggested that it's hypocritical of doctors to support anti-racism protestors now when weeks earlier they denounced large crowds because of the risk of spreading the virus.

Framing anti-racism protests against the control of covid-19 is a false dichotomy. Will crowds possibly lead to more covid-19 cases? Yes. But so will unabated racism.

The data tell part of the story.

Black patients who contract covid-19 are three times more likely to require admission to hospital because of disease severity. ${ }^{1}$ Disproportionately, counties in the US with a large black population account for nearly $60 \%$ of deaths from covid- 19 in the country, despite representing only $22 \%$ of counties. ${ }^{2}$ Most US states have a disproportionate number of covid-19 cases among black patients. ${ }^{3}$ Black patients are less likely to be able to obtain covid-19 tests in several major US cities. ${ }^{4}$ Many black patients have a lower chance of being put on a ventilator where resources are too limited to treat everyone, based on biased algorithms that account for comorbidities and life expectancy. ${ }^{5}$ For black patients, even the decision to wear a mask requires them to weigh the risk of being targeted or even killed by law enforcement against getting covid- $19 .{ }^{6}$

Racism - the explicit and intentional oppression of people from ethnic minorities, not by accident, but by systematic intention for centuries and unabatedly into the present-is the underlying driver of why black patients are at the centre of the US covid-19 epidemic.
As doctors, this is the time to speak up. This is not about politics. This is not about preserving the status quo or being afraid to ruffle feathers. This is about life and death. This is about the fact that in our country, a police officer felt he could put his knee on a black man's neck for 8 minutes and 46 seconds while being filmed.

Staying silent now is saying something. It is saying that the death of an innocent black man at the hands of a brutal white police officer is still not enough for you to put your own skin in the game. We are well aware that institutions suffer from racism. We acknowledge that every one of us holds implicit and explicit biases, and that we must take responsibility and do more to be better, more informed, and more aware as allies to our black community. But doing nothing, and staying silent, is unacceptable.

Many doctors and public health professionals have gained large platforms from the pandemic. It is imperative that they now use those platforms to openly and publicly denounce racism. Racism must be stopped because it is morally deplorable. Additionally, covid-19 cannot be prevented without tackling the underlying drivers for its spread, and racism is undoubtedly one of those in the US. This is clear from the data showing the virus's effects on black communities. The spread of this pandemic is dependent on the exploitation of our societal vulnerabilities and weaknesses-and stopping it demands that we all stand together against racism.

We urge all physicians and public health experts to take a firm stance against racism. We urge that we as a community use our understanding of the science and transmission of covid-19 to protect those who choose to protest peacefully against racism by guiding them with the information necessary to minimise viral transmission. We urge our institutions to make every effort to ensure that our fight against racism within our own walls is transparent; that racist actions and words are seen, heard, and dismantled; that racist people are held to account; that efforts against racism are actively studied and taught as part of our lifelong learning in medicine; that power structures that are based on racist ideologies are taken down and replaced; that people from ethnic minorities are treated with the utmost respect, 
equity, and justice-including in their promotions to positions of leadership; and that patients from ethnic minorities are no longer killed by racism that has haunted medicine since its inception as a field.

There is so much work to be done.

Competing interests: We have read and understood BMJ policy on declaration of interests and declare that we have no competing interests.

1 Rabin RC. Black coronavirus patients land in hospitals more often, study finds. New York Times. 23 May 2020. www.nytimes.com/2020/05/23/health/coronavirus-black-patients.

2 Disproportionately black counties account for over half of coronavirus cases in the US and nearly $60 \%$ of deaths, study finds. Washington Post. www.washingtonpost.com/nation/ 2020/05/06/study-finds-that-disproportionately-black-counties-account-more-than-halfcovid-19-cases-us-nearly-60-percent-deaths.

3 What do coronavirus racial disparities look like state by state? NPR. 30 May 2020. www. npr.org/sections/health-shots/2020/05/30/865413079/what-do-coronavirus-racial-disparitieslook-like-state-by-state.

4 Coleman AR. Retail covid-19 testing is a massive failure for black communities. Vox. 28 April 2020. www.vox.com/2020/4/28/21238423/covid-19-test-cvs-walgreens-blackcommunities.

5 Schmidt $\mathrm{H}$. The way we ration ventilators is biased. New York Times. 15 April 2020. www. nytimes.com/2020/04/15/opinion/covid-ventilator-rationing-blacks.html.

6 McFarling UL. "Which death do they choose?": Many black men fear wearing a mask more than the coronavirus. STAT news. 3 June 2020. www.statnews.com/2020/06/03/ which-deamany-black-men-fear-wearing-mask-more-than-coronavirus.

This article is made freely available for use in accordance with BMJ's website terms and conditions for the duration of the covid-19 pandemic or until otherwise determined by BMJ. You may use, download and print the article for any lawful, non-commercial purpose (including text and data mining) provided that all copyright notices and trade marks are retained.

https://bmj.com/coronavirus/usage 